\title{
Localization is Self-Determination
}

\author{
Hugo Slim* \\ Senior Research Fellow, Blavatnik School of Government, University of Oxford, Oxford, United Kingdom
}

This paper gives a personal political perspective on the policy dispute about localization in the humanitarian sector to argue that localization is a realization of the political right to selfdetermination. It starts by describing how humanitarian aid is too international today. It then makes the case for localization as an essential process of self-determination and humanitarian citizenship. It then analyses the main political arguments used against localization by international humanitarians who are resistant to it and shows how they routinely exaggerate the necessity of international aid by misrepresenting the reality of most humanitarian operations. Finally, the paper makes three recommendations to help humanitarian reform move forwards to find a fairer balance of local, national and international organizations.

Keywords: Localization, humanitarian, self-determination, citizenship, humanitarian contract

\section{INTRODUCTION}

OPEN ACCESS

Edited by:

Kristina Roepstorff, Ruhr-University Bochum, Germany

Reviewed by: Andrew Cunningham, Humanitarian Researcher, United Kingdom Susan G. Harris Rimmer, Griffith University, Australia

*Correspondence: Hugo Slim

hugo.slim@bsg.ox.ac.uk

Specialty section: This article was submitted to Refugees and Conflict,

a section of the journal Frontiers in Political Science

Received: 12 May 2021 Accepted: 25 June 2021 Published: 06 July 2021

Citation: Slim H (2021) Localization is SelfDetermination.

Front. Polit. Sci. 3:708584. doi: 10.3389/fpos.2021.708584
Localization is a matter of self-determination and political justice, not just effectiveness. Building locally-led organizations is about realizing political rights and making humanitarian citizenship, and should be recognized as politically necessary by the international humanitarian leaders who are currently resisting localization.

\section{AID IS TOO INTERNATIONAL TODAY}

In January, the UN's Emergency Relief Coordinator asked governments for a total of $\$ 39.0$ billion dollars to cover the urgent needs of 160 million people suffering the worst effects of armed conflict, disasters and the COVID crisis in 2021. If he gets it, these billions will be spent through the current business model of Western funded humanitarian aid, with only $2 \%$ going directly to national and local organizations.

This business model is top-down and internationally biased. Most official humanitarian aid is financed by Western governments and transferred directly to international organizations, either UN agencies, international non-government organizations (INGOs), the International Committee of the Red Cross (ICRC) and other parts of the Red Cross and Red Crescent Movement. The humanitarian boom of last 20 years has seen these organizations and aid departments of Western governments grow into large transnational bureaucracies with many thousands of employees and multi-billion dollar annual budgets.

With money comes power. Western governments and a few international organizations largely control global humanitarian policymaking, needs assessments and aid allocation, although they are forced to operate within various constraints of time, space and activity imposed by governments and armed groups on the ground. When they team up with government and national, sub-national and community-based organizations, the relationship is mainly one of sub-contracting with international agencies keeping a hierarchical position of power, even if it is described rhetorically as partnership and capacity-building. 
The policy dispute over "localization" rightly arouses strong passions. Many people involved in local and national humanitarian aid feel hurt and insulted by the way the international system describes their society and works within it. They rightly see the current approach as colonial and infused with a white racist gaze that considers national and local organizations inferior in humanitarian intention and capacity. The system holds back the emergence of national humanitarian organizations and national political agreements on humanitarian social contracts within crisis affected societies. The international bias in the system is, therefore, politically and personally offensive.

In 2016, the World Humanitarian Summit (WHS) agreed that humanitarian aid should be "as local as possible and as international as necessary." Also in 2016, Western donor governments and the big international aid organizations struck a deal in "The Grand Bargain" to shift the power and money in humanitarian aid toward local and national organizations. ${ }^{2}$ It has been a stunning failure. In the last year, donor governments and agencies could have made good this failure by adopting faster changes during the COVID crisis to shift the flow of funds, repurpose international organizations and build locally-led programmes. They did not.

\section{THE TWO SIDES REMAIN FIXED}

Localizing arguments turn on political rights and operational effectiveness. They claim that locally-led organizations are better connected to crisis hit communities. This makes them faster responders that are more in tune with community needs and more reliable intermediaries of aid that are there to stay. Champions of locally-led aid also ground their call in political justice and sovereignty. Aid is for people in their countries and so should be put into their hands and enable them to build bigger organizations. People affected, their own organizations and their leaders should be at the center of decisions about aid, its optimal allocation and accountability for its impact. They want to work with international organizations as humanitarian equals and not as sub-contractors.

Ranged against them is the much larger humanitarian establishment. The ministries of foreign affairs and aid departments of Western governments and the big aid organizations they finance like UN agencies, international NGOs (INGO) and the ICRC. Most leaders of the aid establishment prefer the order of the current system. They argue that humanitarian aid needs to be international because of societal collapse in war and disaster which makes a necessity of international aid. At a personal level, there is self-interest too. Greater localization would mean dramatic cuts and job losses in large international organizations if they re-purposed to partnering more than implementing.

${ }^{1}$ The World Humanitarian Summit was a UN-led multi-stakeholder summit held in Istanbul. For more information on its outcome document and many pledges see https://agendaforhumanity.org/summit.html.

${ }^{2}$ See details of the Grand Bargain at https://interagencystandingcommittee.org/ grand-bargain.
People resisting more locally-led humanitarian aid also have serious political concerns. They suspect local aid organizations will fall prey to the political bias intrinsic to the (mis)allocation of resources in contested and corrupt societies. They also want to preserve Western influence through aid in an era of rising authoritarianism. In their view, the current humanitarian order with its proven operational scale and its ability to promote Western values prove the case for a predominantly internationalist system.

The humanitarian establishment are doing what they can to limit localization by reframing it on their terms or playing it into the long grass of Grand Bargain committees, hoping localization is now sliding down the policy agenda again as Western internationalism revives. But, of course, the best way to embed humanitarian and Western values is to build them locally so Western governments should really be insisting on localization.

\section{LOCALIZATION IS SELF-DETERMINATION}

The fundamental moral and political arguments in favor of localization are about self-determination, equal rights and citizenship. Localization is primarily a call for the right to selfdetermination. This fundamental political right is recognized in the first article of the UN Charter and both International Covenants on human rights. ${ }^{3}$ The Charter insists that "friendly relations among nations" should be based "on respect for the principle of equal rights and the self-determination of peoples." The Covenants define this further as: "All peoples have the right to selfdetermination. By virtue of that right they freely determine their political status and freely pursue their economic, social

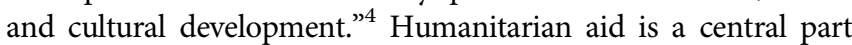
of the economic, social and cultural development of many countries and is also surely intended as one of the most friendly forms of international relations. But the way it is currently organized is deeply unfriendly because it is breaching people's right to self-determination and not treating them as international equals. The strong international bias and control of the current humanitarian aid system is imposing a system of social welfare in their societies which excludes them from its design, and prevents them from building their own social contracts and humanitarian institutions as a people.

A people and a nation have a right to humanitarian selfdetermination which is a key part of "internal" self-determination in a State. Instead, international aid is often operating a system of "subjugation, domination and exploitation" of people's humanitarian self-organization which are the three key markers of disrespecting and repressing self-determination. ${ }^{5}$ Each society must work out for itself, in its ethics, politics and

${ }^{3} \mathrm{UN}$ Charter Article 1; Article 1 of the International Covenant on Civil and Political Rights, and Article 1 of the International Covenant on Social, Economic and Cultural Rights.

${ }^{4}$ Article 1, paragraph 1 of both International Covenants.

${ }^{5}$ For a seminal discussion of self-determination and human rights, see Robert McCorquodale, Self-Determination: A Human Rights Approach, The International and Comparative Law Quarterly Vol. 43, No 4, October 1994 pp.857-885 
institutions, how to treat one another humanely in a crisis and support the common good. This means agreeing humanitarian norms internally and then building and honoring organizations that save lives, reduce suffering and respect human beings. Humanitarian self-determination takes time and is always a work in progress. It is never finished because politics and society changes and new crizes arise. Every society needs humanitarian institutions to emerge from within, and then belong to its social and political culture even if they are also influenced by religious or political norms that exist internationally as well. The moral and political sustainability of humanitarian institutions is extremely important to a society. This makes investment in localization a matter of political rights and a strategic use of humanitarian funds for the long-term.

Interestingly, when Western humanitarians work in other people's countries, they tend to bring with them, unconsciously and consciously, a utopian vision of a selforganizing society with strong welfare commitments and institutions which limit human suffering. This is the gradual historical experience of their own countries and they would be wise to support it in others. Instead, cuckoo-like, they often create a parallel international system in other people's countries which prevents humanitarian self-determination in two main ways. First, internationalism typically misses deep processes of humanitarian self-determination that are already underway in institutions that internationals cannot easily see as they drive past them in their white Toyotas to bigger offices designed specifically for internationalism, with gates, guards and parking. Secondly, internationalism goes wrong by thinking that self-determination can be done for people. It cannot. A people can be inspired and supported by internationalism as they determine and build their humanitarian institutions but they have to make them themselves and argue with each other while they build them. Otherwise, it these institutions are not theirs.

Both these errors overlook the importance of national citizenship and prioritize the obligations of global citizenship instead. But supporting a people's efforts in humanitarian selfdetermination means treating them as equals and recognizing that the place of crisis is their society not yours. As national citizens, it is their responsibility to build humanitarian organizations. International humanitarians are not good at this supportive role when they are in a hurry, which they usually are, because they typically work with rapid staff turnover, one year budget cycles and a twelve month view of reality. This hurry is surely one of the reasons why many national and local humanitarian leaders feel unseen and pushed past in their own country by a system which treats them more as subjects than citizens.

Humanitarian citizenship is part of people's citizenship - an agreement between them and government that their lives are cared for and important. Citizenship needs a humanitarian contract between a people, its government and its institutions. This contract must be made within the State. The dominance of international aid agencies often disastrously diverts the process of humanitarian contract-making so that it emerges between a government and international organizations instead of a government and its peoples. This contract error can delay the making of a real humanitarian contract for decades.

People arguing for localization are demanding the right to play their part as citizens to build their humanitarian contract and so determine the norms, institutions and practices for their own country. To do this properly, they need to stop being the humanitarian subjects of an international aid emperor in Geneva and New York who liaizes over their heads with their government on humanitarian matters.

\section{INTERNATIONAL RESISTANCE TO LOCALIZATION}

International humanitarianism has two particular moral and political responsibilities: to protect people against national humanitarian failures, and to ensure there are global norms and fairness in the distribution of limited aid.

The first responsibility is the source of most international resistance to localization. Internationalists think their ability to protect people from national humanitarian failures will be seriously weakened by localization for two reasons. First, because societal collapse makes locally-led aid operationally unrealistic. Secondly, because of the political risk of international resources going to national and local organizations which are then politically captured by politicians who do not care about any of the their people, or only care about some of them.

These pragmatic political concerns make internationalists think localization may be a waste of money and time that is bound to make them fail in their most important duty to protect people from national humanitarian failure. They hear localization as the call of political idealists, which flies in the face of evidence in actual aid operations. Their recent experience in armed conflicts seems to prove them right. In countries like Iraq, Syria, Yemen, Central African Republic and Nigeria, international aid agencies have seen government institutions collapse and vital employees flee in fear of their lives or because they have been unpaid for months. International agencies have felt bound to step in at scale with money, equipment and expertize. They have also had to use their international leverage to insist that people are helped who governments and local leaders have no desire to help. International humanitarians, therefore, argue that the "necessity" of international aid is much more widespread than advocates of locally-led aid are willing to admit.

Another reason that internationals suspect localization is because they find its analysis of aid organizations too simplistic. They find localization advocates too purist in their definition of national, local and international organizations. Like Roepstorff, they see that local, national and international relationships are much more "entangled" than localization advocates admit. ${ }^{6}$ Some local organizations are the creation of

${ }^{6}$ Roepstorff, Kristina (2020) A Call for Reflection on the Localization Agenda in Humanitarian Action, Third World Quarterly, 41:2, 284-301. 
powerful members of the international diaspora who are no longer neither local nor national in any meaningful way. Many international organizations, like CARE, World Vision, Oxfam or Caritas, have branches that are deeply national or local in some ways. Many aid agencies seem genuinely to be "hybrids" that combine the local, national and international. Importantly, national and local humanitarian leaders are often protected in such hybrids, when they might be politically assaulted in a simpler local organization. This organizational ambiguity is the cause of delays in agreeing a definition of a national or local agency in the Grand Bargain committees.

These various political reasons make internationalists argue that effective aid is necessarily international in many situations, and that international organizations are not as international as localists make out. In my view, internationalists are right on two counts but wrong in one major way which undercuts their positive arguments.

First, they are right that many organizations are hybrids of some kind and so the measure of localization needs to be flexible. But this flexibility should not be cynically exploited by international agencies keen to horde policy, power and resources for themselves. Secondly, investing in national and local organizations can be politically unwise because of capture in certain situations. But political risk is too often used by donors and international agencies as a lazy alibi for not trying to support locally-led organizations. In just as many situations, proper international partnership could support national and local humanitarian organizations under pressure. Discounting them is dismissive of their political rights and sub-contracting them is exploitative.

\section{EXAGGERATING INTERNATIONAL NECESSITY}

It is in their weighing of international necessity that internationalists make their major error. They misrepresent humanitarian aid as mostly managing extreme situations and so over-emphasize a zero sum game between local institution building and life-saving in a context of societal collapse and political risk. In reality, this situation is very seldom the case and, where it is the case, it is not the case for very long.

The great majority of humanitarian aid is invested far away from the extreme life and death moments of violence and disaster. Instead, most aid flows into more stable humanitarian holding operations which support displaced people, basic services and wider human rights work in protection in conditions of relative social order. These humanitarian operations typically last for many years and involve repeatedly servicing the same communities, like the displaced in Syria, Iraq, and South Sudan, the Rohingyas in Bangladesh, and Nigerians in Maiduguri and wider Borno state. In truth, the typical humanitarian operation is much closer to a pro-poor development program in a context of chronic poverty than it is to a fast-moving disaster response.

In these majority humanitarian settings, the necessity for international agency is low and the possibility of local and national agency is very high. This leaves donor governments and international organizations with no reason to avoid investing in national and local organizations. Indeed, it is profoundly negligent of internationals to have been operating in these places for decades and left such a small trace of empowered national humanitarian organizations and improved humanitarian social contracts between citizens and governments.

Equally important is internationalist misrepresentation of societal collapse and the weakness of local humanitarian order in emergencies. In fact, it is precisely in moments of collapse and crisis that new humanitarian activism, leaders and organizations are born. ${ }^{7}$ Crisis and societal collapse is precisely the right time, and the ripe time, to be working with an emergent humanitarian movement in society and not overpowering it. We have seen this vividly around the world in the COVID pandemic where new national organizations and local mutual aid societies have flourished.

All international humanitarians work for humanitarian organizations and with humanitarian norms that were created in the conflict, collapse and crisis of their own societies: the ICRC, the UN, Save the Children, IRC, Oxfam and many more. This should tell them that crisis is a highly creative moment for local and national humanitarian organizations, a time of humanitarian growth and not collapse. It is the best moment to invest in them and not the time to pretend they are weak or do not exist.

\section{MOVING FORWARDS}

To rise to the pressing challenges of global COVID vaccination and increasing climate crisis, three things need to happen fast to realize people's political right to locally-led aid.

1. Western donor governments and international aid organizations must recognize humanitarian selfdetermination as a necessity. The current WHS slogan "as local as possible and as international as necessary" puts the more powerful ethical and legal principle of necessity on the side of international aid, and only a weaker "possibility" of primacy on the side of locally-led aid. This is wrong. The basic premise of humanitarian aid should be that it is "nationally and locally led with international support." Necessity falls first on locally-led aid and international agencies have a moral and political duty to respect and enable a nation's right to humanitarian self-determination before they insist on their own international rights.

2. Both parties need to recommit to the $25 \%$ target of direct funding to national and local organizations and start making it happen. This is a relatively small step which leaves $75 \%$ of aid flows international. Achieving the $25 \%$ can be set about now in a pragmatic spirit which sees flexibility from both sides on definitions and the hybrid nature of many aid organizations.

${ }^{7}$ Marie Berry, War, Women and Power: From Violence to Mobilization in Rwanda and Bosnia-Herzegovina, Cambridge University Press, Cambridge. 
Everyone in the aid sector needs to understand that this shift of power and resources means difficult re-purposing and painful organizational change for local and international organizations.

3. Two former Heads of State should be tasked by the UN Secretary General to take oversight responsibility for the $25 \%$ change and the shift in humanitarian business model one from an aid receiving nation and the other from a Western donor country. Their role should be to move the change process from inside the Grand Bargain committee into an operationally focused executive team to drive the change and grow the vision of success.

Reforming global systems is notoriously hard and takes many years without a major shock to catalyze deep change. If humanitarian reform is genuinely to move forwards and be politically just, it must now recognize the necessity of humanitarian self-determination within individual States as equal to the necessity of international aid from the collective action of many States.

\section{DATA AVAILABILITY STATEMENT}

The original contributions presented in the study are included in the article/supplementary material, further inquiries can be directed to the corresponding author.

\section{AUTHOR CONTRIBUTIONS}

The author confirms being the sole contributor of this work and has approved it for publication.

Conflict of Interest: The author declares that the research was conducted in the absence of any commercial or financial relationships that could be construed as a potential conflict of interest.

Copyright (c) 2021 Slim. This is an open-access article distributed under the terms of the Creative Commons Attribution License (CC BY). The use, distribution or reproduction in other forums is permitted, provided the original author(s) and the copyright owner(s) are credited and that the original publication in this journal is cited, in accordance with accepted academic practice. No use, distribution or reproduction is permitted which does not comply with these terms. 